\title{
Morphology and Physiology of Cortical Neurons in Layer I
}

\author{
Shaul Hestrin ${ }^{1,2}$ and William E. Armstrong ${ }^{1}$ \\ Departments of ${ }^{1}$ Anatomy and Neurobiology and ${ }^{2}$ Neurology, University of Tennessee, Memphis, Tennessee 38163
}

The electrophysiological and morphological properties of layer I neurons were studied in visual cortex slices from 7- to 19-dold rats using whole-cell recording and biocytin labeling. A heterogeneous population of small, nonpyramidal neurons was found. Approximately one third of the cells we recorded were neurogliaform cells; another third were multipolar neurons with axons descending out of layer I. The remaining cells were heterogeneous and were not classified. In slices from 7- to 10-d-old animals only, we identified Cajal-Retzius cells.

Neurogliaform neurons had a very dense local axonal field, which was largely contained within layer I. Cells with descending axons had a relatively sparse local axonal arbor and projected at least to layer II and sometimes deeper. Spiking in neurogliaform neurons was followed by an afterdepolarizing potential, whereas spiking in cells with descending axons was followed by a slow after-hyperpolarizing potential (AHP). In addition, neurogliaform cells exhibited less spike broadening and a larger fast AHP after single spikes than did cells with descending axons. Generally, cells in layer I received synaptic inputs characterized as either GABA- or glutamate-mediated, suggesting the presence of excitatory and inhibitory inputs.

With their output largely limited to layer I, neurogliaform cells could synapse with other layer I neurons, the most distal dendritic branches of pyramidal cells, or the dendrites of layer II/III interneurons, which invade layer I. Cells with descending axons could contact a wide variety of cortical cells throughout their vertical projection.

Key words: neurogliaform; Cajal-Retzius; afterdepolarization; afterhyperpolarization; excitation; inhibition
Layer I of the neocortex is relatively cell-sparse and contains mostly nonpyramidal neurons (Prieto et al., 1994). This low density and the location immediately beneath the pial surface has hampered detailed studies of the cellular elements in layer I. In particular, there have been only few studies of layer I neurons using intracellular recordings (Martin et al., 1989; Zhou and Hablitz, 1996).

Ramon y Cajal (1911) described a horizontal cell type, later named the Cajal-Retzius (CR) cell, and several types of "shortaxon" cells in layer I. The CR cells are observed only rarely in adult tissue (but see Condé et al., 1994), whereas the short-axon cells of layer I are maintained in adult cortex. The majority of layer I cells (90-95\%) stain for glutamate decarboxylase or GABA and therefore may be GABAergic (Gabbott and Somogyi, 1986; Winer and Larue, 1989; Li and Schwark, 1994; Prieto et al., 1994). Moreover, most of the cells in layer I have smooth dendrites or only a few spines, suggesting that these may be similar to interneurons or nonpyramidal cells in layers II-VI. Most of the information reported has been obtained using Golgi techniques, some of which may not reveal fine axonal projections. We used patch-clamp techniques (Edwards et al., 1989) to record from visually identified layer I neurons and obtained physiological and morphological characterization of these cells.

\footnotetext{
Received Feb. 20, 1996; revised June 4, 1996; accepted June 5, 1996.

This work was supported by National Eye Institute Grant EY-09120 (S.H.) and National Institutes of Health Grant NS-23941 (W.E.A.). We thank Mario Galarreta and Charlie Wilson for their help, Bob Foehring for comments on this manuscript, and Emin Kuliyev for his excellent technical assistance.

Correspondence should be addressed to Shaul Hestrin, Department of Anatomy and Neurobiology, College of Medicine, University of Tennessee, 855 Monroe Avenue, Memphis, TN 38163.

Copyright (C) 1996 Society for Neuroscience $\quad 0270-6474 / 96 / 165290-11 \$ 05.00 / 0$
}

\section{MATERIALS AND METHODS}

Slice preparation. Parasagittal slices (300 $\mu \mathrm{m}$ thick) from the visual cortex of 7- to 19-d-old rats (Wistar) were obtained using a vibroslicer (Campden). Ice-cold recording solution (see below) was used during slicing. The slices were maintained at $35^{\circ} \mathrm{C}$ for $1 \mathrm{hr}$. Slices were kept at room temperature during the recording. The solutions were bubbled with a gas mixture of $95 \% \mathrm{O}_{2} / 5 \% \mathrm{CO}_{2}$.

Recording. Patch pipettes (3-5 M $\Omega$ ) were made from thin-wall $(1.5 \mathrm{~mm}$ outer diameter, $1.17 \mathrm{~mm}$ inner diameter) borosilicate glass (Clark) using a vertical electrode puller (PP83, Narishige). Whole-cell recordings (Edwards et al., 1989) were made from layer I neurons selected under visual control using an upright microscope (Zeiss, standard 16, fixed stage) with Nomarski differential interference contrast optics using a water immersion lens $(40 \times 0.75 \mathrm{NA})$. Whole-cell recordings in current-clamp or voltage-clamp mode were obtained using a patch-clamp amplifier (List EPC-7). No correction is made for the pipette junction potential (approximately $-10 \mathrm{mV}$ ). The voltage and current output were filtered at 1 or $2 \mathrm{kHz}$ (Frequency Devices, Haverhill, MA) and digitized at 12-bit resolution (TL1, Axon Instruments, Foster City, CA). After electrophysiological characterization, the pipette was withdrawn from the cell, and the slice was processed for histology (see below). Miniature excitatory or inhibitory synaptic currents were recorded in the presence of the sodium channel blocker tetrodotoxin (TTX) (Sigma, St. Louis, MO) and detected off-line using a tape storage device (Vetter, Rebersburg, PA). Data were digitized at 10 or $20 \mathrm{KHz}$ and transferred to a disk. Miniature detection was based on threshold crossing of a set amplitude compared with a baseline amplitude. Miniatures were aligned at the 50\% amplitude. An exponential function was fitted to each event. The rise times (20-80\%), amplitudes, and decay time constants were stored in a separate ascii file used for the construction of histograms.

Solutions. The recording solution contained (in $\mathrm{mM}$ ): $126 \mathrm{NaCl}, 2.5$ $\mathrm{KCl}, 1.25 \mathrm{KH}_{2} \mathrm{PO}_{4}, 1 \mathrm{MgSO}_{4}, 2 \mathrm{CaCl}_{2}, 26 \mathrm{NaHCO}_{3}$, and 10 glucose, $\mathrm{pH}$ $7.4(305 \mathrm{mOsm})$. Pipettes were filled with a solution containing (in $\mathrm{mm}$ ): $144 \mathrm{~K}$-gluconate, $3 \mathrm{MgCl}_{2}$, 10 HEPES, 0.2 EGTA, $4 \mathrm{MgATP}$, and $0.3 \mathrm{NaGTP}, \mathrm{pH} 7.2$ (295 mOsm). For labeling neurons, biocytin (0.1$0.3 \%$; Sigma) was added to the pipette internal solution. To record miniature inhibitory postsynaptic currents (mIPSCs), we used a chloride-rich internal solution that contained (in mM): $80 \mathrm{~K}$-gluconate, $40 \mathrm{KCl}, 10$ HEPES, $4 \mathrm{MgATP}, 20$ creatine phosphate (Na), $0.3 \mathrm{GTP}$, and 10 EGTA, pH 7.2 (295 mOsm). The AMPA receptor antagonist 


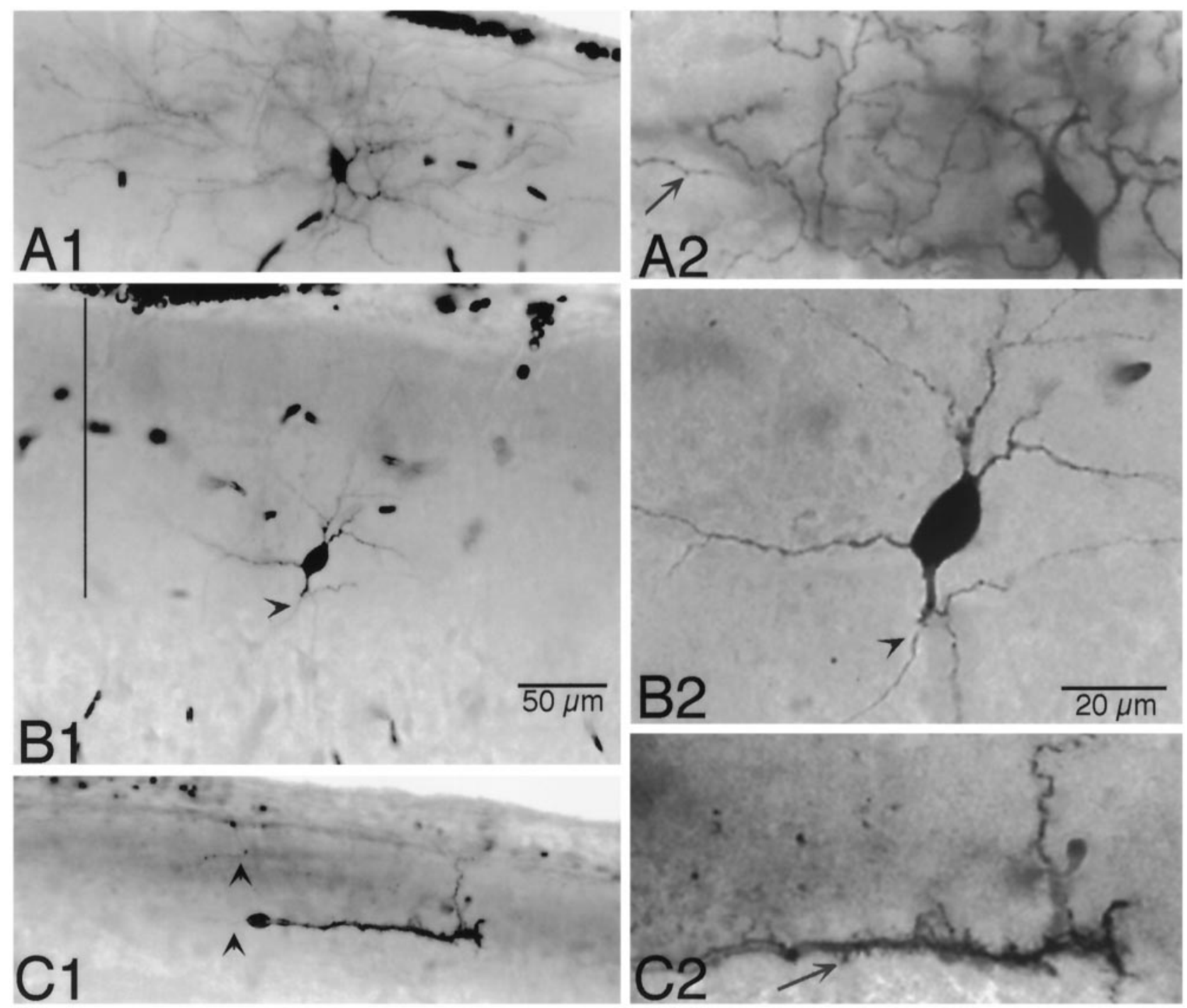

Figure 1. Photomicrographs of layer I biocytin-stained neurons. $A$, Low-power $(A 1)$ and high-power $(A 2)$ micrograph of a neurogliaform cell located in the central portion of layer I. The axonal and dendritic arbors are contained within layer I. Note the extensive axonal arborization of this cell type in $A 2$. The arrow points to a varicosity along the axon. B, Low-power (B1) and high-power (B2) micrograph of cell with descending axon (arrowhead) located near the border of layers I and II. Vertical bar delimits layer I. Both dendrites and axons are present in layers I and II. This neuron is drawn in Figure 5. $C$, Low-power $(C 1)$ and high-power $(C 2)$ micrograph of a CR cell found close to the pial surface of layer I (9-d-old rat). Both the axon (arrowhead) and the dendrite run parallel to the pial surface. This neuron is drawn in Figure 2. Scale bar in B1 applies to lower-power micrographs; Scale bar in B2 applies to high-power micrographs.

6-cyano-7-nitroquinoxaline-2,3-dione (CNQX) (RBI) and the GABA antagonist picrotoxin (RBI) were dissolved in aqueous solution.

Histology. Slices were fixed overnight in a solution of $4 \%$ paraformaldehyde, $0.2 \%$ picric acid in 0.15 m sodium phosphate buffer $(\mathrm{pH} 7.2-7.4)$ at $4^{\circ} \mathrm{C}$. After thorough rinsing in PBS, the slices were incubated for $6-18$ $\mathrm{hr}$ in avidin-biotin-horseradish peroxidase complex (ABC; Vector Labs, Burlingame, CA) in PBS containing $0.5 \%$ Triton X-100. The slices were rinsed four times in PBS and then reacted in a solution containing $0.06 \%$ 3-3' diaminobenzidine, $0.03 \% \mathrm{H}_{2} 0_{2}$, and $0.01-0.05 \%$ nickel ammonium sulfate for $\sim 30 \mathrm{~min}$. The slices were then cleared and mounted in a $50-50 \%$ solution of glycerol-PBS. The coverslips were sealed with fingernail polish for storage. Filled neurons were drawn with a Nikon Optiphot microscope equipped with a drawing tube. Figures of drawn neurons were created after the drawings were scanned at $300 \mathrm{dpi}$ (Hewlett Packard ScanJet IIcx). Digital micrographs were acquired with a cooled CCD camera (Photometrics, Tucson, AZ) with a frame resolution of $1200 \times 1500$. Photomontages of individual neurons were created from several focal planes. Final figures were constructed in Adobe Photoshop on a Power Macintosh, where contrast adjustments were made and paste marks removed. Micrographs were printed to a Tektronix Phaser 440 printer at 300 dpi.
Statistics. All error terms listed are SD. Between-group comparisons were made with a two-tailed Mann-Whitney $U$ test.

\section{RESULTS}

We were able to recover histologically $\sim 50 \%$ of all recorded cells. This article is based on 32 cells that were characterized both morphologically and electrophysiologically. All of the recorded cells could be classified as nonpyramidal neurons, as described earlier (Ramon y Cajal, 1911; Marin-Padilla, 1984). We characterized the pattern of action-potential trains in response to current injection, and in some cases we also studied the cells under voltage clamp. We found that neurons in layer I are heterogeneous in morphology. Most cells could be classified as neurogliaform cells, cells with descending axons, or early in development, CR cells. Photomicrographs of representative cells belonging to these three classes are shown in Figure 1. The remaining cells (about one third) were mostly multipolar, but were not classified 


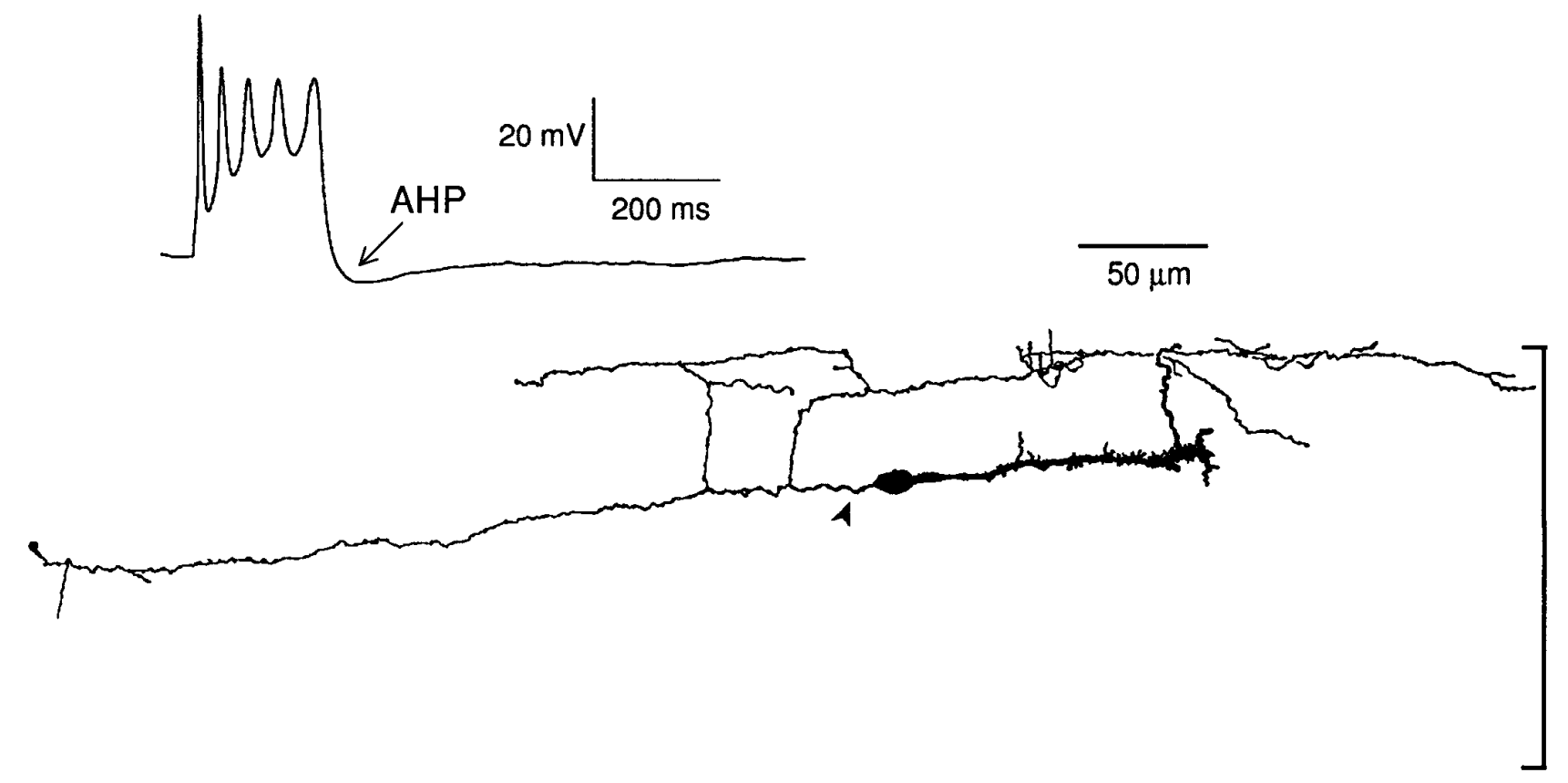

Figure 2. The projection tube drawing of a biocytin-stained CR cell (same cell as in Fig. 1) from a 9-d-old animal. The arrowhead indicates the possible site of axon origin. Note the location of the cell in the upper portion of layer I (indicated by the bracket at right of the drawing). Note also the thick single dendrite with small finger-like appendages. Inset, A response to an injection of depolarizing current. Note slow action-potential time course and progressive increase in spike width. Resting potential was $-50.5 \mathrm{mV}$.

further because the axon was not stained intensely enough to determine whether it arborized within layer I or descended to deeper layers.

\section{CR cells}

CR cells are thought to be the first postmitotic cells that appear during embryonic development (Marin-Padilla, 1984; Bayer and Altman, 1990; Derer and Derer, 1990; Huntley and Jones, 1990). Biocytin labeling from cells in slices obtained from 7- to 9-d-old rats revealed CR-like cells $(n=6$; Fig. $1, C 1, C 2)$. These neurons were characterized by an orientation largely horizontal to the one to three primary processes that arose from a round-to-ovoid soma $(16.3 \pm 4.5 \times 10.3 \pm 2.5 \mu \mathrm{m})$. Four of the six cells were bipolar in appearance, with two processes extending laterally from each pole of the soma. One process was thick, with a roughly contoured appearance resulting from a high density of appendages. These appendages varied from small spine-like protrusions to longer filiform processes. Often the thicker process expanded distally. From the opposite somatic pole, the opposing process was thin and axon-like, as in Figure 2. Both thick and thin processes could give rise to thin, vertical branchlets, which in turn could branch and project horizontally (Fig. 2). These thin processes extended anteroposteriorly several hundred micrometers.

The remaining two CR cells had processes with a similar morphology except that the bipolar orientation was not evident. Regardless, a thin process arose directly from either the soma or a thick process and projected several hundred micrometers beneath the pial surface, branching frequently. All of the CR cells were located in the upper half of layer I. In older rats (11-19 d), we recovered no cells with the unique CR morphology.

The average resting potential of CR cells was $-64.4 \pm 8 \mathrm{mV}$, and all CR cells were electrically active, as action potentials could be initiated with depolarizing current (Fig. 2, inset). These spikes had a long duration (half-width: $3.9 \pm 0.7 \mathrm{msec}$ ). Trains of spikes were not always induced and when present were characterized by pronounced spike broadening and amplitude reduction. The input resistance of CR cells was high $(610 \pm 163 \mathrm{M} \Omega)$.

\section{Neurogliaform cells}

Eight of the 26 cells we recorded in slices from 11- to 19-d-old rats had a very dense axonal arbor that was contained almost entirely within layer I, and these were characterized as neurogliaform cells (Figs. $1 A 1, A 2,3$ ). In addition to the dense local axonal arbor, neurogliaform cells had five to six smooth and short primary dendrites that were restricted to layer I, and a small smooth soma $(15.7 \pm 4.3 \times 9.9 \pm 1.9 \mu \mathrm{m})$. Distally, all of the processes, but particularly the axon, were very thin and required highmagnification, oil-immersion optics to be followed. Neurogliaform cells were typically located in the middle to upper half of layer I. The axonal projection field could extend throughout the dorsoventral extent of the layer and anteroposteriorly 200-300 $\mu \mathrm{m}$ and could fill the thickness of the slice. The density of the arborization and the thinness of the processes often made distinguishing axons from dendrites difficult.

The average resting potential of neurogliaform cells was $-62.0 \pm 6.8 \mathrm{mV}$, and their average input resistance and membrane time constant were $500 \pm 166 \mathrm{M} \Omega$ and $71 \pm 42 \mathrm{msec}(n=$ 8 ), respectively. Current injections from resting potential elicited single spikes at threshold level (Fig. 4A). Action potentials had a short half-width $(1.2 \pm 0.2 \mathrm{msec})$ and a large fast afterhyperpolarization potential (fAHP), measured as the difference between spike threshold and the peak hyperpolarization immediately after the spike $(-19.9 \pm 2.3 \mathrm{mV})$. In response to suprathreshold current injection, spike trains were often interrupted by quiescent periods (Fig. 4B). Larger current injection resulted in an uninterrupted train of spikes showing some spike frequency adaptation in all but one neuron, which responded with only one spike. In addition to these characteristics, we also found that seven of the 


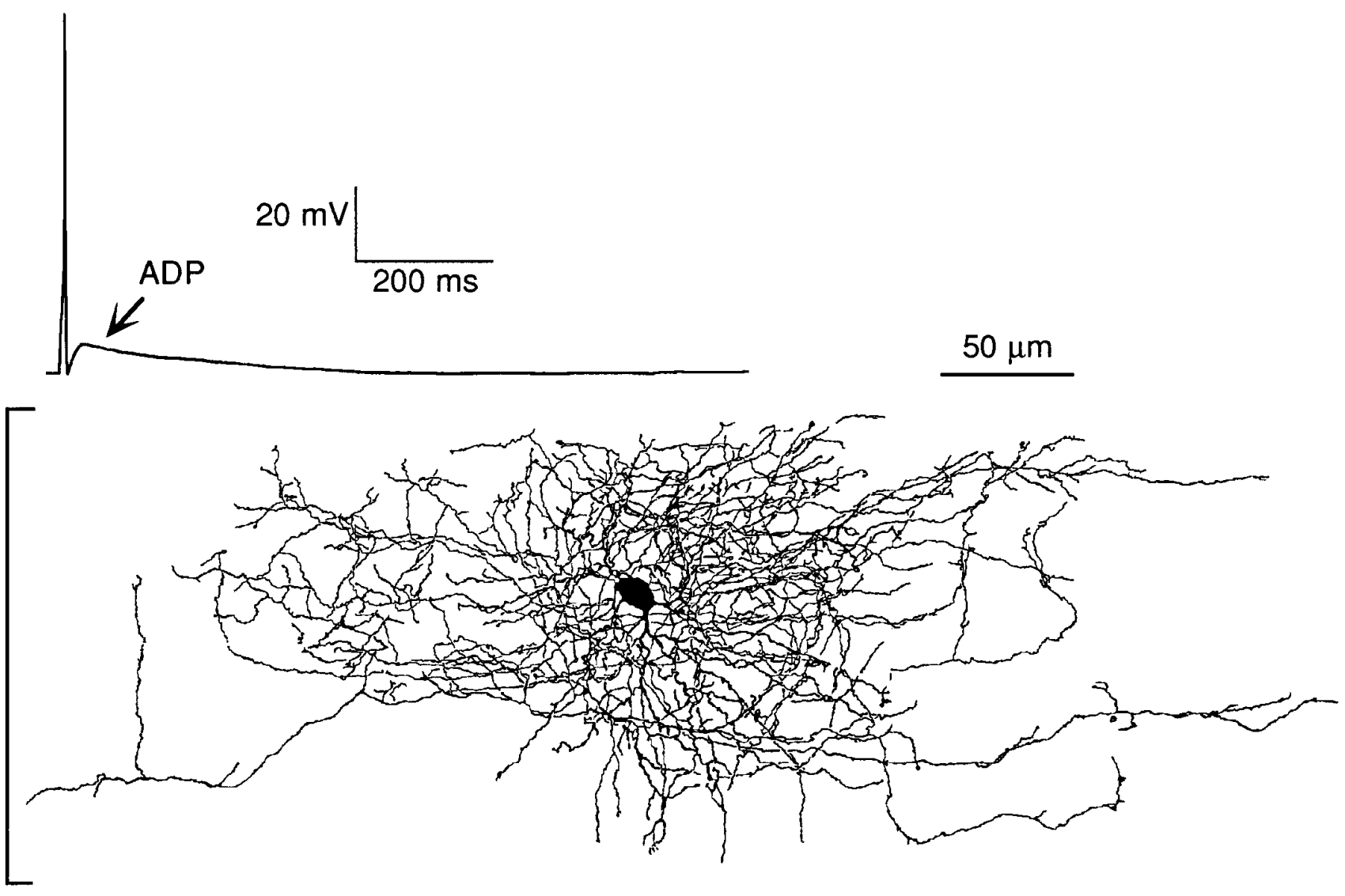

Figure 3. A projection tube drawing of a biocytin-stained neurogliaform cell in layer I. Borders of layer I are indicated at left of the drawing. The extensive axonal arbor extends close to the border of layer I but does not enter layer II. The central location of the somata is typical of these cells. Inset, A single action potential initiated in this cell by current injection $(300 \mathrm{pA}, 10 \mathrm{msec})$ is followed by an afterdepolarization $(A D P)$. Resting potential: $-56 \mathrm{mV}$.

eight neurogliaform neurons tested exhibited a slow membrane depolarization after action potentials $(+5.8 \pm 1.7 \mathrm{mV})$ (Figs. 3, inset, $4 B-D)$. This afterdepolarization (ADP) peaked at $60.1 \pm$ $28.7 \mathrm{msec}$ after the termination of a single spike or a short train of action potentials and repolarized slowly with a time constant of $203 \pm 60.2 \mathrm{msec}$ (Figs. 3, inset, 4B-D). The ADP was observed after a train of spikes (Fig. $4 C, D$ ) or could be initiated by a single spike (Fig. 3, inset; see Fig. 8D). The ability of cells to generate an ADP was not strongly dependent on the resting membrane potential. Under membrane hyperpolarization to $-80 \mathrm{mV}$ or more negative, however, the rising phase of the ADP was obscured by the spike repolarization. As will be shown below, the current underlying the ADP is inward at the resting membrane potential. Also shown in Figure $4 A$ is a depolarizing sag that developed with stronger membrane hyperpolarization, which was found to some degree both in neurogliaform cells and in cells with descending axons.

\section{Cells with a descending axon}

Seven of the 26 cells from 11- to 19-d-old rats had an axon that descended to layer II or deeper (Figs. 1B1,B2, 5). Like neurogliaform cells, the somata were small $(14.9 \pm 3.4 \times 7.9 \pm 1.7 \mu \mathrm{m})$ but were typically found in the middle to lower half of layer I. These cells had four to five sparsely branching dendrites. Two of the seven neurons had spiny dendrites, whereas the remaining five were relatively aspiny. For most of these neurons, the dendritic tree extended from the top to the bottom of layer I; additional dendritic projections were commonly found in the upper half of layer II. The anteroposterior extent of dendritic spread, however, was limited to $<200 \mu \mathrm{m}$ from either side of the soma. The distal portions of the dendrites were thin, as were secondary and tertiary branches. The single axon arose from either the soma or a primary dendrite. Although the axon sometimes branched within layer I, the local arborization was sparse when compared with that of neurogliaform cells. Scattered axonal branches were also found in deeper layers, and varicosities were often visible along collateral branches. The axon of two neurons reached layer IV and that of a third reached layer $\mathrm{V}$. The remaining neurons had axons restricted to layers I and II. Collateral branches in deeper layers were not observed to extend anteroposteriorly much beyond $\sim 100$ $\mu \mathrm{m}$ from the cell body. The axons were thin distally, however, and the staining was faint, and we cannot rule out a more extensive projection.

The resting potential $(-63.8 \pm 5.1 \mathrm{mV})$, input resistance $(756 \pm 308 \mathrm{M} \Omega)$, and membrane time constant $(79 \pm 27 \mathrm{msec})$ of cells with a descending axon were not significantly different from those of neurogliaform cells. These cells responded with a single spike to threshold stimulation and under suprathreshold current injection fired a steady train of action potentials. Action potentials had a half-width of $1.7 \pm 0.3 \mathrm{msec}$ and an fAHP of $-12.2 \pm 1.7$ $\mathrm{mV}$. Compared with neurogliaform cells, the fAHP was smaller $(p \leq 0.02)$, whereas the action-potential half-width was longer $(p \leq 0.02)$. During a spike train, there was spike frequency adaptation (Fig. 6A), and action potentials were broadened (Fig. 7). Cells with a descending axon exhibited more frequency adap- 


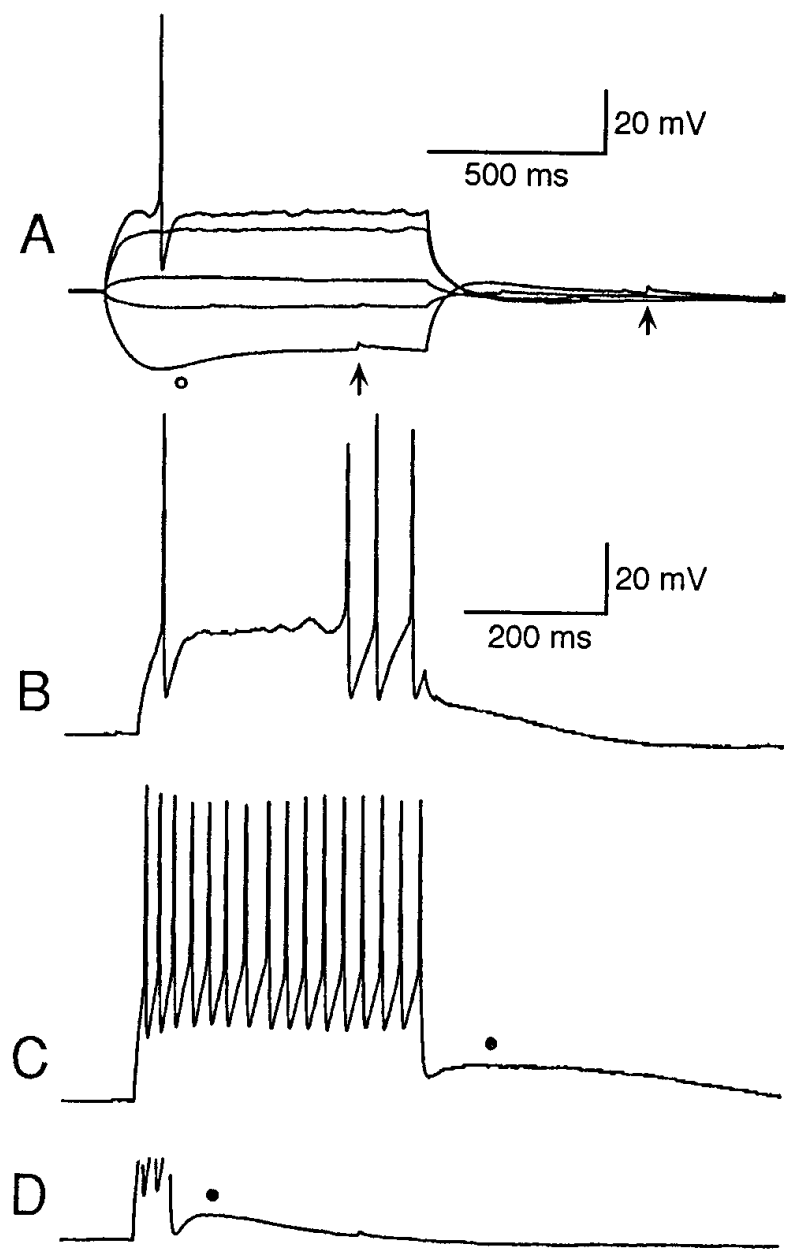

Figure 4. Action-potential characteristics of a neurogliaform cell. All records are from the same cell. $A$, Steps $(900 \mathrm{msec})$ of current injection $(-30,-10,+10,+50$, and $+70 \mathrm{pA})$ from resting potential $(-65 \mathrm{mV})$. Note that the response to hyperpolarizing current injection $(-30 \mathrm{pA})$ suggests the presence of an inward rectification, as indicated by the sag (open circle). At threshold, a single spike was evoked with a large fAHP. Note the PSPs (arrows) indicated by the fast rise and slow decay with a peak of $\sim 1 \mathrm{mV}$. $B$, A depolarizing current injection above threshold evoked a single spike followed by a quiescent period preceding further spikes. Note the prolonged depolarization after current cessation. $C$, Suprathreshold current injection evokes a train of spikes with little frequency adaptation. Note the ADP after current injection ( filled circle). D, ADP ( filled circle) initiated by short-duration current injection. Resting potential: $-65 \mathrm{mV}$.

tation than did neurogliaform cells. The ratio of the spike frequency of the fourth to the first interspike interval from briefly evoked spike trains was $0.85 \pm 0.1$ versus $0.70 \pm 0.14$ in neurogliaform cells and cells with descending axons, respectively ( $p \leq$ $0.05)$. After a train of spikes, cells with a descending axon exhibited an AHP (Fig. 6B2). An AHP was also induced by a single spike (Fig. 6B1). The average amplitude and decay time constant of the AHP were $-5.1 \pm 2.7 \mathrm{mV}$ and $211.6 \pm 44.0 \mathrm{msec}$, respectively. Because of the more extensive spike broadening exhibited by cells with descending axons, the differences in the half-width and fAHP between these and neurogliaform cells were accentuated when the second spike was examined, and together these two features clearly distinguished the two cell types (Fig. 7). A single cell with a descending axon displayed a notch after the action potential, and an action potential could be triggered after a rebound from hyperpolarization (data not shown).

\section{Other neurons}

Three neurons were recovered that had an axon apparently restricted to layer I but did not locally arborize with the density of neurogliaform cells and thus were not classified as such. In addition, some of the dendrites extended into layer II. None of these three cells exhibited an ADP, and only one exhibited the slow AHP characteristic of cells with descending axons. Soma size averaged $16.8 \pm 1.4 \times 9.1 \pm 0.5 \mu \mathrm{m}$.

The remaining neurons from which we recorded physiological data and recovered a stained neuron were left unclassified because the axon was not well stained. These cells were morphologically and electrophysiologically diverse; two exhibited an ADP and had short dendrites restricted to layer I, reminiscent of neurogliaform cells; five had a slow AHP and longer dendrites that often extended into layer II. Soma size ranged from $15.2 \times$ $2.6 \mu \mathrm{m}$ for the largest to $10.4 \times 7.2 \mu \mathrm{m}$ for the smallest neuron.

\section{Voltage clamp}

The slow time course of the ADP and AHP displayed by the neurogliaform cells and cells with a descending axon, respectively, may reflect slowly relaxing voltage-dependent currents or may be driven by calcium or other second messengers. Under currentclamp conditions, the time course of the ADP or AHP depends on voltage-dependent conductances and the membrane time constant and therefore may not represent the kinetics of the underlying conductance waveform. Figure 8 illustrates AHPs and ADPs in cells with a descending axon (Fig. $8 A, C$ ) and in neurogliaform cells (Fig. $8 B, D$ ), respectively. Under voltage clamp, a brief membrane depolarization induced a slowly developing outward current in neurons with an AHP (Fig. 8C,C1) and an inward current in cells with an ADP (Fig. 8D,D1). The decays of the I-AHP and I-ADP had a time course of several hundred milliseconds, similar to that of the voltage traces after action potentials. Furthermore, the I-ADP had a clear rising phase, suggesting that this current does not represent a tail current but reflects a slow response to events triggered by brief membrane depolarization.

The AHP has been observed in several cell types and is generated by an increase in K-conductance (for review, see Sah, 1996). The mechanisms underlying the ADP, however, have not been established. It has been suggested that in pyramidal and nonpyramidal neurons the ADP may reflect a calcium tail current, a decrease of potassium conductance (Constanti et al., 1993), an electrogenic ion pump (Friedman et al., 1992), or a nonselective cationic conductance (Caeser et al., 1993). We measured the voltage dependency of the conductance underlying the ADP by stepping the membrane potential to various voltages at the peak of the I-ADP (Fig. 9A). The tail-current amplitude, defined as the difference between the steady-state current at the end of the trace and the current just after the voltage step plotted against the membrane voltage, indicated a reversal potential near $-50 \mathrm{mV}$ (Fig. 9B). These data suggest that the conductance mechanism is most likely an increase in mixed cationic conductance rather than a decrease in potassium conductance or calcium tail current.

\section{Excitatory and inhibitory synaptic inputs}

Synaptic contacts in layer I of both symmetrical and asymmetrical types have been found (Beaulieu and Colonnier, 1985; Beaulieu et al., 1994). The functions of these synapses in relation to layer I neurons have been noted only recently (Hablitz and Zhou, 1995). To characterize these inputs further, synaptic currents were recorded, under voltage clamp, in the presence of TTX $(0.5 \mu \mathrm{M})$ to prevent asynchronous release of neurotransmitter. In these re- 


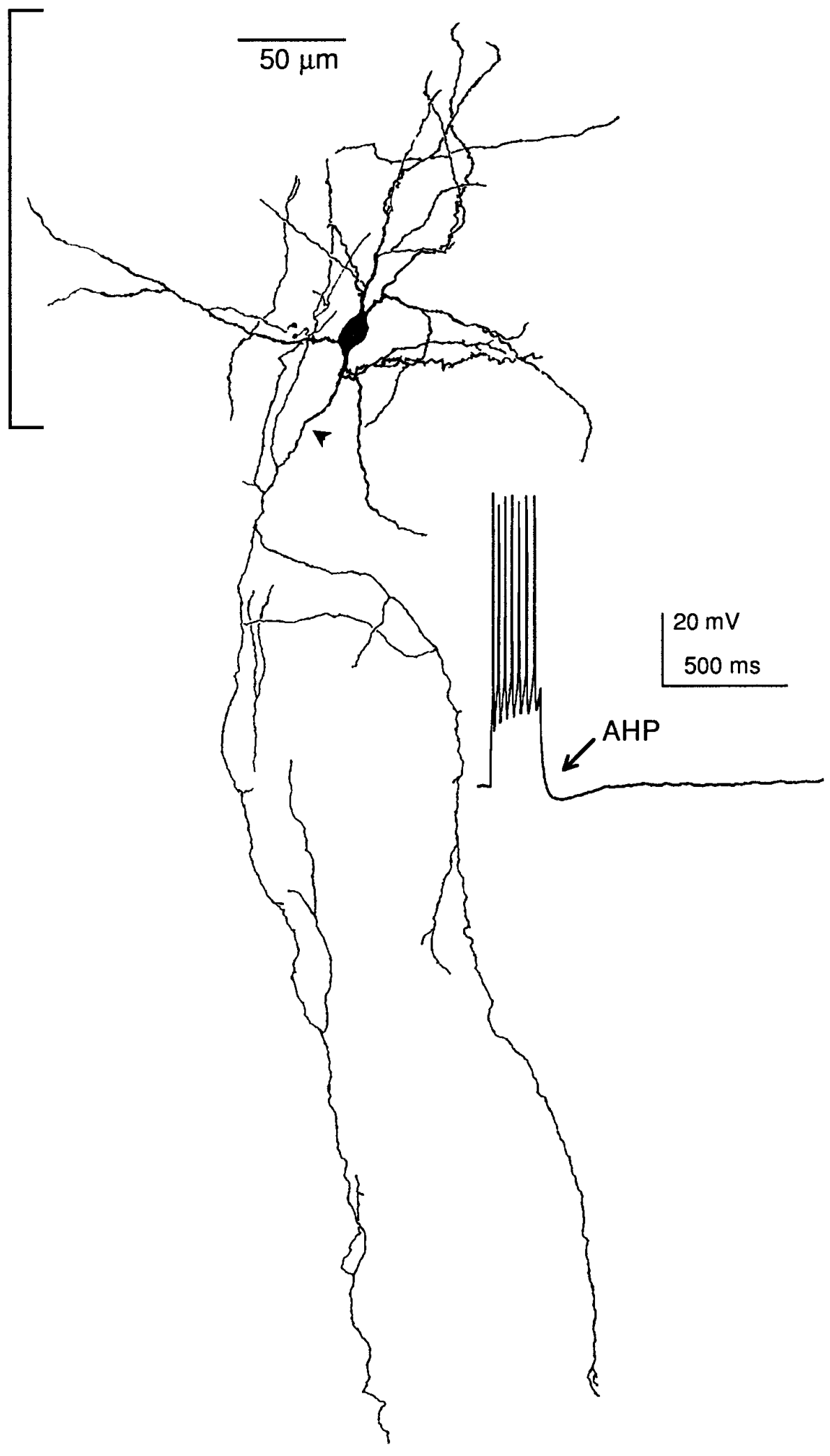

Figure 5. Cell with a descending axon. Soma is located close to layer I-II border (indicated at left of drawing). The axon, whose origin is indicated by arrowhead, descends well into lower layers but gives off a local arbor. Inset, A train of spikes is followed by an afterhyperpolarization $(A H P)$. Resting potential: $-59 \mathrm{mV}$; current injection: 150 pA, $200 \mathrm{msec}$. cordings, biocytin was not included in the pipette solution. Synaptic currents recorded under these conditions are quantal events thought to originate from single synaptic contacts. We used pharmacological agents to isolate either the AMPA receptor-mediated excitatory postsynaptic currents (EPSCs) or GABA receptormediated IPSCs.
When the GABAergic blocker picrotoxin $(100 \mu \mathrm{M})$ was present, the synaptic currents observed at $-70 \mathrm{mV}$ were excitatory inward currents (Fig. 10A1). Application of the AMPA receptor antagonist CNQX $(10 \mu \mathrm{M})$ blocked these currents, indicating that these are AMPA receptor-mediated miniature EPSCs (mEPSCs). To minimize the possible attenuation of synaptic currents by den- 


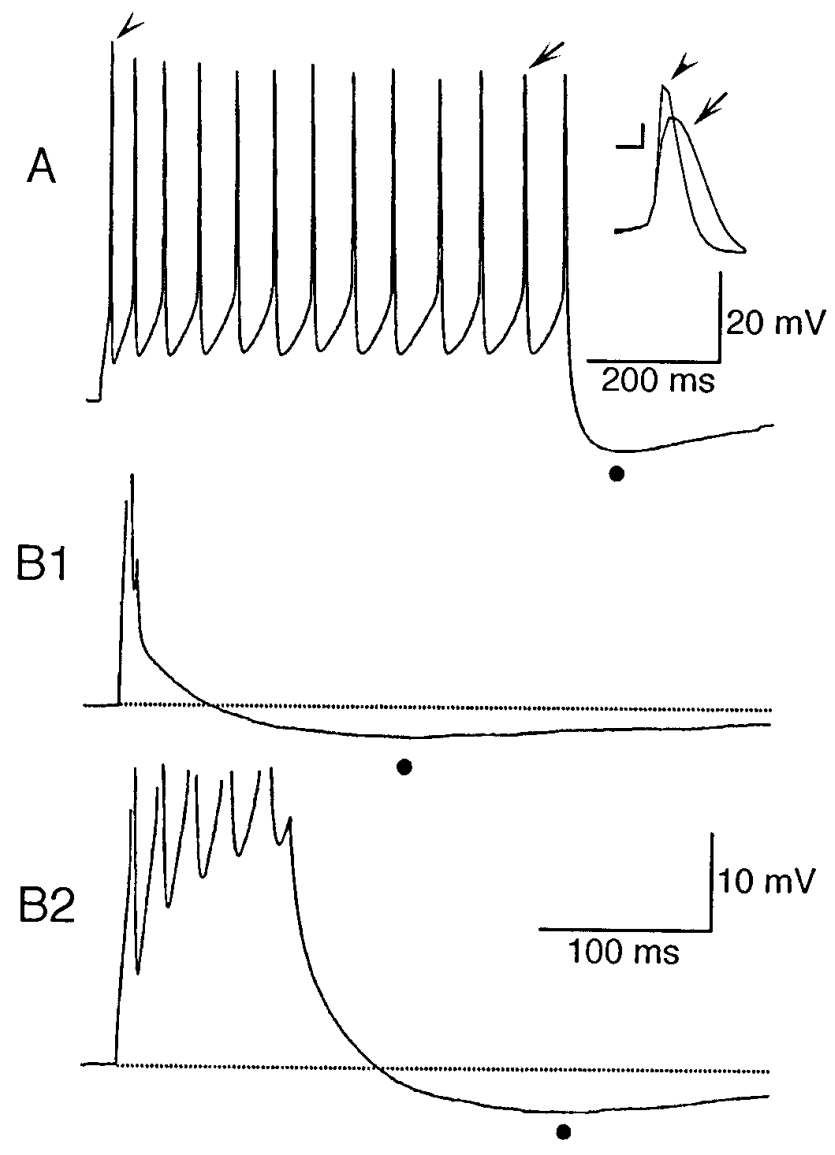

Figure 6. Action potential characteristics of cells with descending axon. $A$, Depolarization induced a train of action potentials illustrating spike frequency adaptation. Note the spike broadening during the train. After the train there is an AHP (indicated by filled circle). Resting potential: -59 $\mathrm{mV}$; current injection: $+100 \mathrm{pA}, 700 \mathrm{msec}$. Inset, Superimposition of the first (arrowhead) and the twelfth (arrow) spikes of the train. Note the broadening of the action potential. Spike width at half amplitude was 1.7 msec (first) and $3.4 \mathrm{msec}$ (twelfth). The spikes were aligned at the threshold. Scale is $2 \mathrm{msec}, 10 \mathrm{mV}$. B1, B2, A different cell exhibiting an AHP after a single spike (B1) or a short train of spikes (B2). Resting potential: $-62 \mathrm{mV}$; current injection: $220 \mathrm{pA}, 10 \mathrm{msec}(B 1)$ and $120 \mathrm{pA}$, $100 \mathrm{msec}($ B2). The AHPs are indicated by filled circles.

dritic filtering, we selected miniature currents with a rise time faster than $0.3 \mathrm{msec}$. Under these conditions, the distribution of mEPSCs (Fig. 10A2) was skewed to the right. The mean amplitude of the mEPSCs was $18.6 \pm 4.6 \mathrm{pA}(n=7)$. Assuming that the AMPA receptor-activated conductance has a reversal potential near $0 \mathrm{mV}$, the conductance of the mEPSCs is 265.7 $\mathrm{pS}$. Individual mEPSCs were well fitted with a single exponential function. The decay time constants were narrowly distributed about the mean (Fig. 10A3). The average decay time constant was $2.2 \pm 0.5 \mathrm{msec}(n=7)$.

To record IPSCs, we filled the patch pipettes with chloride-rich internal solution (see Materials and Methods). The estimated chloride reversal potential under these conditions is $-20 \mathrm{mV}$. Therefore, the IPSCs recorded at $-70 \mathrm{mV}$ should produce an inward current. Inhibitory synaptic currents were recorded in the presence of TTX $(0.5 \mu \mathrm{M})$ and the AMPA receptor antagonist CNQX $(10 \mu \mathrm{M})$. Application of picrotoxin blocked these synaptic currents, indicating that these were mIPSCs. For analysis, we selected mIPSCs with a rise time of $<0.6 \mathrm{msec}$. The inward currents recorded under these conditions had slower decay kinet-

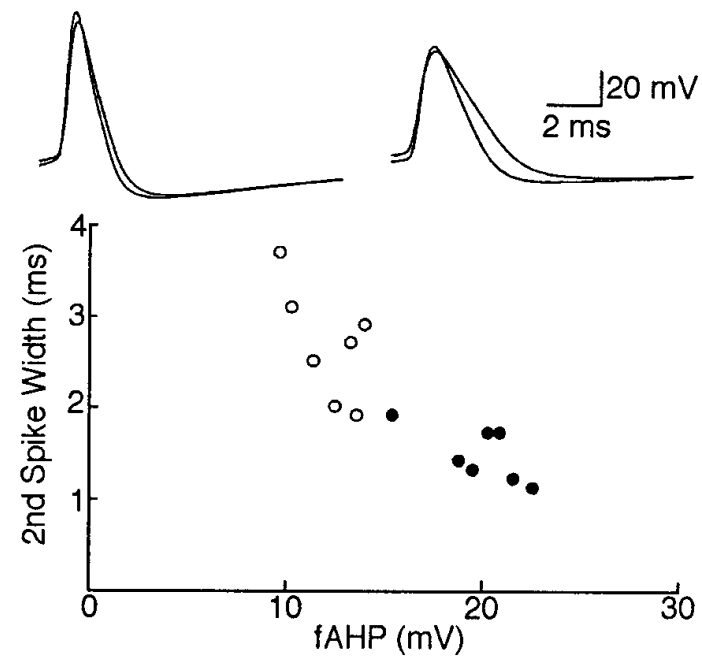

Figure 7. Action potential parameters in neurogliaform cells and cells with descending axons. The $f A H P$ plotted against the half-width of the second spike in a train of spikes. The $f A H P$ of neurogliaform cells ( filled symbols) is larger in amplitude than that of cells with descending axons (open symbols). The second spike half-width of the neurogliaform cell is shorter in duration compared with that of cells with descending axons. Inset, Superimposition of the first and second spikes in a train of action potentials. Inset left, Neurogliaform cell; inset right, cell with descending axon.

ics compared with that of the mEPSCs (compare Fig. 10, $A 1$ and $B 1$; note the different time scale). The peak amplitudes of the mIPSCs exhibited a skewed distribution (Fig. 10B2) similar to that of the mEPSCs. The average mIPSC was $29.9 \pm 4.9 \mathrm{pA}(n=6)$. Assuming that the reversal potential of the IPSC is $-20 \mathrm{mV}$, we estimate that the quantal conductance of the IPSCs is $598 \mathrm{pS}$. When fitted with single exponential function, the mIPSCs were significantly slower compared with the mEPSCs, and the decay time constants were broadly distributed (Fig. 10B3). We found, however, that the mIPSCs were better fitted with a dual exponential function (see Materials and Methods). The average fast time constant was $5.7 \pm 2.2 \mathrm{msec}$, and the slow component was $30.1 \pm$ $15.5 \mathrm{msec}(n=6)$. The average relative amplitudes of the fast and slow component were $62.3 \%$ and $37.7 \%$.

\section{DISCUSSION}

Our main finding is that within layer I, there are distinct groups of small neurons that can be differentiated by their axonal projection and electrophysiological properties. In particular, we identified a group of neurogliaform cells with a very dense axonal field contained within layer I and a second group of neurons with an axon descending to the lower cortical layers. In addition, these two cell types exhibit different electrophysiological properties. Neurogliaform cells and cells with a descending axon are morphologically distinct from the CR cells observed in younger rats.

\section{Neurogliaform cells}

Neurogliaform cells have been described by several authors (Jones, 1984). Ramon y Cajal (1911) reported neurogliaform cells in layer I that he also called spiderweb or dwarf cells. Neurogliaform cells have been described in layer I of human newborn infants (Marin-Padilla, 1984) and in the rat visual cortex (Hedlich and Werner, 1987). Martin et al. (1989) used intracellular recording and HRP injection to obtain the receptive field properties and morphology of a single, layer I neuron. The morphology of that 

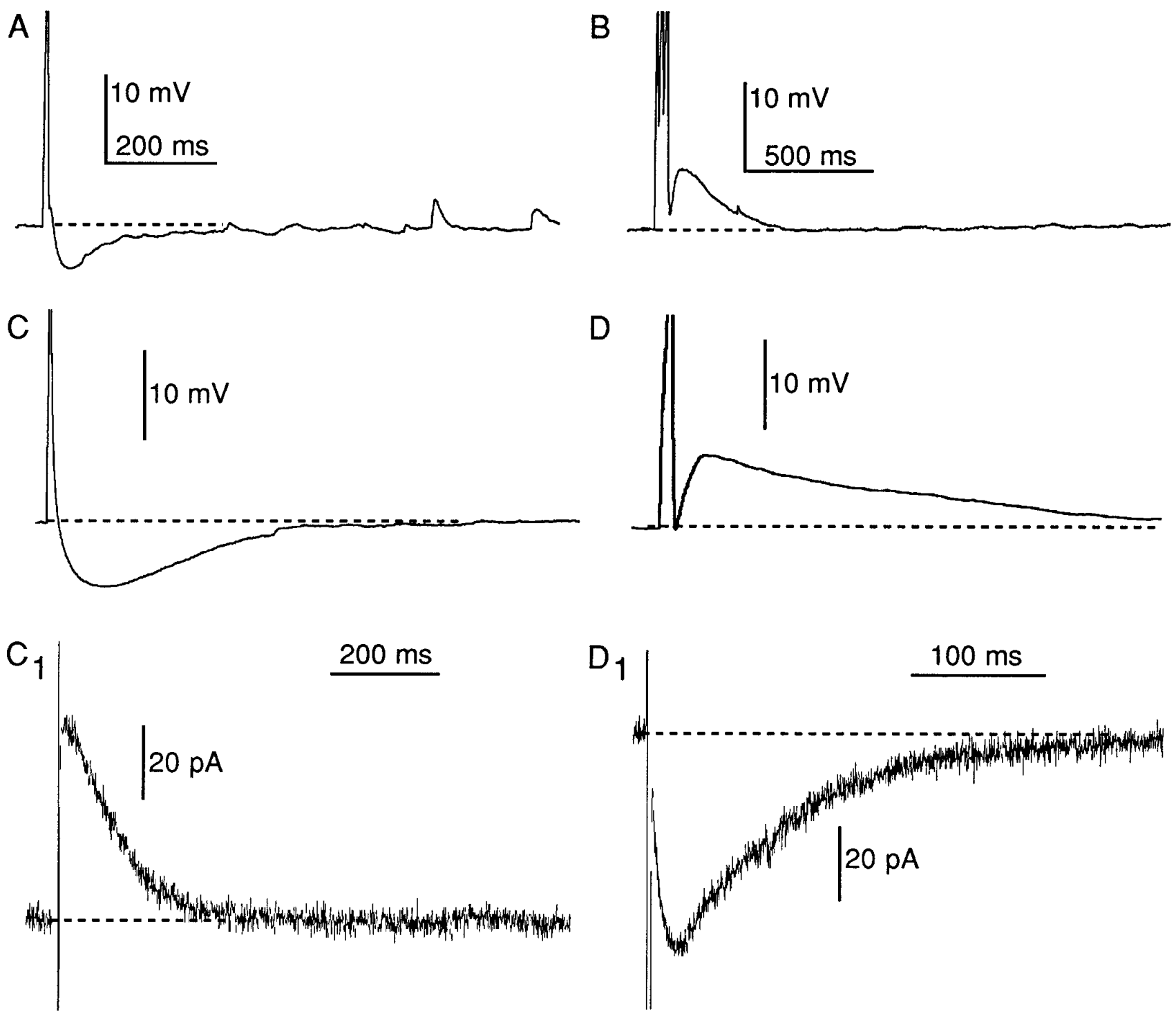

Figure 8. AHP and ADP. A, AHP after a single action potential in a cell with a descending axon. Note the PSPs at the end of the voltage trace. Resting potential: $-65 \mathrm{mV}$; current injection: $+200 \mathrm{pA}, 10 \mathrm{msec}$. $B$, ADP in a neurogliaform cell induced by a short train of spikes. Note the small PSP occurring at the decay phase of ADP. Resting potential: $-62 \mathrm{mV}$; current injection: $+200 \mathrm{pA}, 50 \mathrm{msec}$. Current injection: $C$ and $C 1$, AHP and I-AHP in a single cell. I-AHP is induced by a brief $(10 \mathrm{msec})$ depolarizing pulse of membrane potential to $+20 \mathrm{mV}$ from a holding potential of $-60 \mathrm{mV}$. Note that the I-AHP $(C 1)$ has a time course similar to the AHP $(C) . D$ and $D 1$, ADP and I-ADP in a single neurogliaform cell. Under current clamp $(D)$, depolarizing current $(+300 \mathrm{pA}, 10 \mathrm{msec})$ induced a single spike from a resting potential of $-61 \mathrm{mV}$. I-ADP was induced by a $2 \mathrm{msec}$ voltage step to $20 \mathrm{mV}$ from a holding potential of $-65 \mathrm{mV}(D 1)$. Note the slow rising phase of the response under voltage clamp.

cell is similar to that of the neurogliaform cells we describe here (compare Fig. 2 of Martin et al., 1989, and Figs. 1 and 2 in this paper). Sousa-Pinto et al. (1975), Winer and Larue (1989), and Anderson et al. (1992) have not identified neurogliaform cells in layer I, but this may reflect incomplete staining of the fine axons. The robust filling of neurogliaform cells we have obtained in some cells revealed a very dense axonal arbor that rarely extended beyond the border of layer I. These data suggest that neurogliaform cells synapse primarily onto targets within layer I. These targets could include the dendrites of pyramidal neurons, dendrites from nonpyramidal neurons of layer II/III (Kawaguchi, 1995), and other layer I neurons. Kawaguchi (1995) described neurogliaform cells in layer II/III of frontal cortex after biocytin filling, with morphological characteristics remarkably similar to those reported herein.
It has been shown previously that spiking parameters can be used to differentiate pyramidal from nonpyramidal cortical neurons (McCormick et al., 1985; Connors and Gutnick, 1990). Further differentiation among cortical nonpyramidal neurons in layers II-VI has also been observed (Foehring et al., 1991; Kawaguchi, 1993, 1995, 1996; Kawaguchi and Kubota, 1993). The electrophysiological properties of neurogliaform cells have been studied only by Kawaguchi (1995), who found that these cells exhibit a delayed spike occurring at the end of a depolarizing current pulse. We have not observed the late spiking behavior in layer I neurogliaform cells, which possibly reflects different conditions of our experiments or perhaps a difference between layer I and layer II/III neurogliaform cells. We found, however, that layer I neurogliaform cells exhibit a characteristic ADP after spikes, which was not reported by Kawaguchi (1995). Cortical 

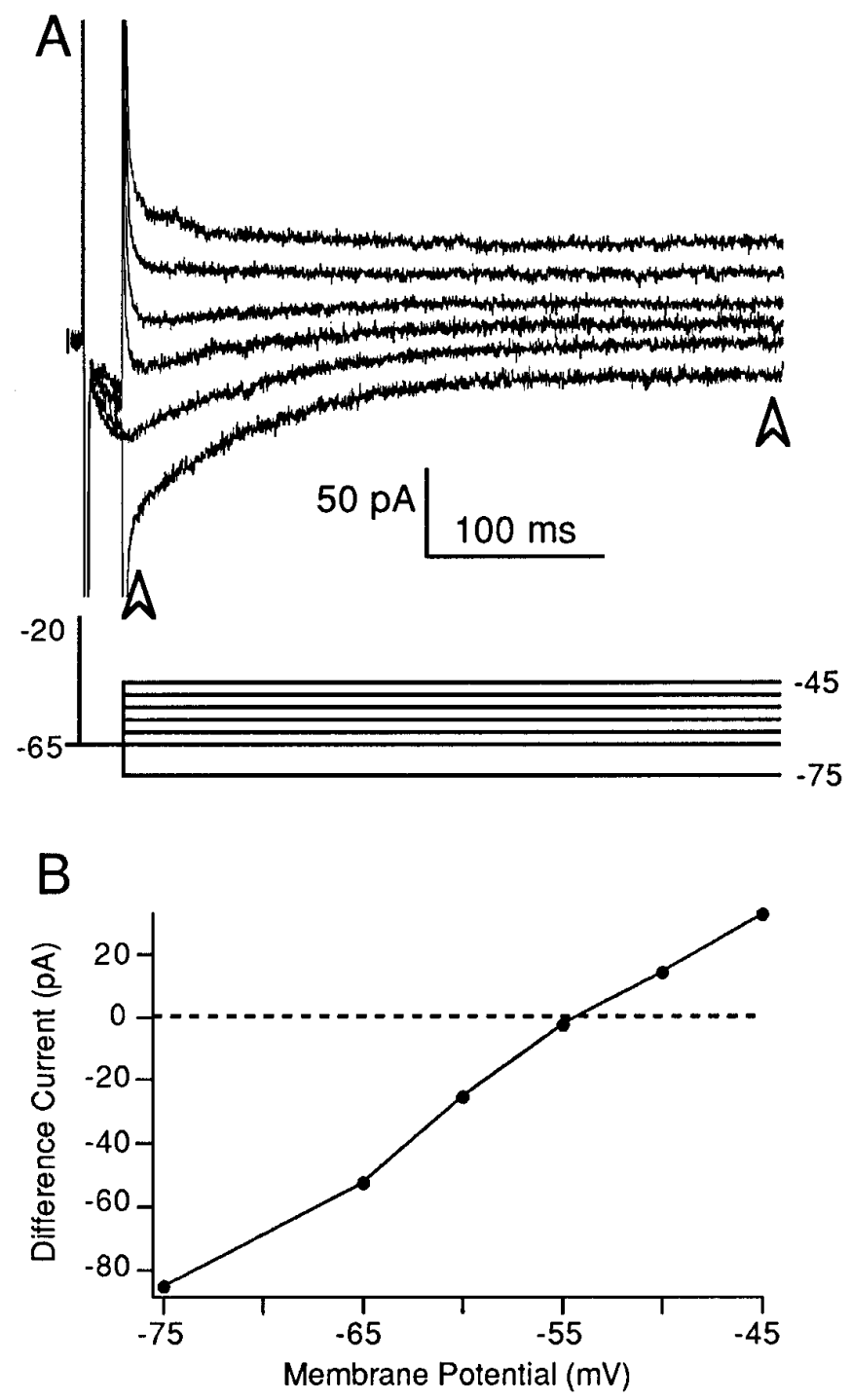

Figure 9. Conductance mechanism of the I-ADP. $A$, The membrane potential was $-65 \mathrm{mV}$. A brief $(2 \mathrm{msec})$ voltage pulse to $-20 \mathrm{mV}$ initiated the I-ADP. At the peak of the I-ADP, the membrane potential was stepped to different voltages: $-75,-65,-60,-55,-50$, and -45 as shown diagrammatically beneath the current traces. Note that the tail current after a step to $-75 \mathrm{mV}$ was larger than that observed at more depolarized voltages, indicating that the reversal potential was more depolarized than $-75 \mathrm{mV} . B$, The current-voltage relationship of the tail currents was obtained by subtracting the current (averaged over $5 \mathrm{msec}$ ) measured at the time indicated by the right open arrow from the current just after the voltage step at the time indicated by the left open arrow. Note that the tail current reversed polarity at approximately $-50 \mathrm{mV}$. Same cell as that shown in Figure $8 D$.

pyramidal neurons also exhibit a form of ADP, the time course of which is typically faster than the ADP in neurogliaform cells (Friedman and Gutnick, 1987; Schwindt et al., 1988; Foehring and Waters, 1991). Under voltage clamp, brief depolarization of neurogliaform cells generated a slow inward current (I-ADP) with kinetics similar to those of the ADP, suggesting that the time course of the ADP is not reflecting the membrane time constant but rather a slow conductance. The reversal potential of approximately $-50 \mathrm{mV}$ suggests a mixed cationic conductance. A cationic conductance is thought to underlie the ADP of hippocampal pyramidal cells induced by activation of glutamate metabotropic and cholinergic muscarinic receptors (Caeser et al., 1993).
In response to a steady current injection, layer I neurogliaform cells fire action potentials characterized by a large fAHP and less frequency adaptation and spike broadening when compared to cells with descending axons. Spike frequency adaptation and spike broadening are prominent in most pyramidal neurons and are found to a lesser degree in some nonpyramidal cells (Kawaguchi, 1995, 1996).

\section{Cells with descending axons}

We have identified a group of cells that had a prominent descending axon in addition to their local collateral projections. The characteristics of cells with a descending axon have not been studied extensively in the literature; however, Ramon y Cajal (Fig. 54 in DeFelipe and Jones, 1988) described layer I cells, which he called cells with descending axons, that had been discovered previously by Schaffer in 1897 (cited in DeFelipe and Jones, 1988). He described them as being located in the lower part of layer I, and they seem to correspond to the cells with descending axons that we describe here.

It is not possible to determine from our material whether the axons extend to the white matter, because the axonal staining became faint distally. Martínez-García et al. (1994) found that some cells in the inner half of layer I project to the contralateral visual cortex. Therefore, it may be that some of the cells we classify as cells with descending axons provide input to distant regions in addition to the collateral inputs seen in deeper cortical layers.

Cells with a descending axon are clearly differentiated from neurogliaform cells both morphologically and electrophysiologically. Compared with neurogliaform cells, those with a descending axon exhibit a smaller fAHP and a larger spike width. The slow AHP and frequency adaptation seen in cells with a descending axon recall the regular spiking nonpyramidal cells described by Kawaguchi $(1995 ;$ 1996) in layers II/III and V. Cells with a descending axon are morphologically similar to the subclass of nonpyramidal neurons that are immunoreactive for vasoactive intestinal polypeptide (Kawaguchi, 1996).

\section{CR cells}

CR cells are among the first postmitotic cells. Recent findings suggest that they are important developmentally (Ogawa et al., 1995); however, their fate in the adult cortex has not been resolved. Only a few authors have reported on CR cells in the adult brain (Condé et al., 1994; Martínez-García et al., 1994). Indeed, we have identified CR cells only in relatively young animals (7- to 9-d-old). Presently it is not known whether CR cells die at early postnatal age, change their morphology, or diminish in proportion to other proliferating cells (MarinPadilla, 1984; Bayer and Altman, 1990; Derer and Derer, 1990; Huntley and Jones, 1990; del Rio et al., 1995). Electrophysiologically, CR cells are active, as has been shown recently by Zhou and Hablitz (1996) (Fig. 2, inset), and their spike parameters are similar to immature cortical neurons (Kriegstein et al., 1987; McCormick and Prince, 1987; Lorenzon and Foehring, 1993; Kim et al., 1995; Zhou and Hablitz, 1996).

\section{Unclassified cells}

Our reticence to classify approximately one third of the neurons reflects what we consider to be weak or incomplete staining of axonal arbors. In addition, the morphologies of a few well filled neurons simply could not be generalized to other groups of neurons and stood as isolated examples. It is likely that layer I contains other distinct groups of neurons that we have not iden- 

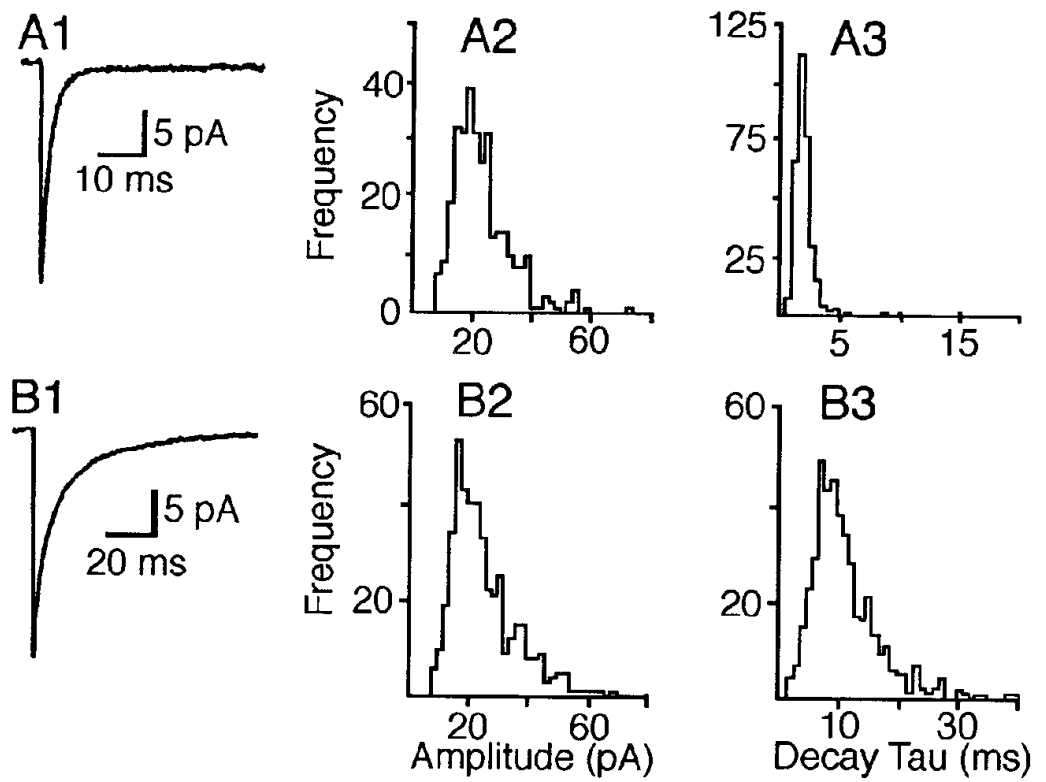

Figure 10. mEPSCs and mIPSCs. $A 1-A 3$, mEPSCs were detected using a threshold amplitude of $-6 \mathrm{pA}$ (see Materials and Methods). TTX $(0.5 \mu \mathrm{M})$ and picrotoxin $(100 \mu \mathrm{M})$ were present. The membrane potential was $-70 \mathrm{mV}$. A1, Average of 266 aligned mEPSCs with a rise time $(20-80 \%)$ of $<0.3$ msec. The amplitude for the threshold detection was set at -6 pA. $A 2$, The distribution of the mEPSC amplitudes $(n=318)$. $A 3$, Distribution of decay time constants fitted to individual mEPSCs. B1-B3, mIPSCs recorded at a membrane potential of $-70 \mathrm{mV}$ in the presence of TTX $(0.5 \mu \mathrm{M})$ and CNQX (10 $\mu \mathrm{M}$ ). Chloride-rich internal solution was used (see Materials and Methods). B1, Average of 450 mIPSCs with a rise time $<0.6 \mathrm{msec}$. The amplitude for the threshold detection was set at $-8 \mathrm{pA}$. Note the different time scale and the relatively slow decay of the mIPSCs compared with that of the mEPSCs. B2, Distribution of the mIPSCs amplitudes. B3, Histogram of the decay time constants obtained by fitting individual mIPSCs with a single exponential function. tified simply because they were insufficiently represented in our study.

\section{Functional implications}

The overwhelming majority (90-95\%) of neurons in layer I are GABAergic (Gabbott and Somogyi, 1986; Winer and Larue, 1989; Li and Schwark, 1994; Prieto et al., 1994). Lambolez et al. (1996) found that the AMPA receptors in layer I neurons have a GluR1-4 subunit composition that is characteristic of layers II-VI nonpyramidal neurons (Geiger et al., 1995). Moreover, the response to rapid application of glutamate in layer I neurons (Lambolez et al., 1996) is similar to that of other nonpyramidal neurons (Hestrin, 1993; Jonas et al., 1994). Thus, most layer I neurons can be classified, morphologically as well as physiologically, as being similar to inhibitory neurons found elsewhere in the cortex.

We found that layer I neurons receive both excitatory and inhibitory synaptic inputs. The excitatory input may be derived from collaterals of local pyramidal neurons and/or extracortical projection, including thalamic fibers. The source of inhibition is probably other neurons in layer I, but axons of inhibitory neurons from the lower layers may also contribute.

The predominant postsynaptic elements within layer I are the distal portions of apical dendrites from pyramidal neurons in layers II-V. Cortical inputs that selectively target layer I may undergo significant electrotonic attenuation (Cauller and Connors, 1994). Pyramidal cell dendrites, however, may generate sodium and/or calcium spikes that could boost synaptic inputs (Huguenard et al., 1989; Pockberger, 1991; Amitai et al., 1993; Kim and Connors, 1993; Magee et al., 1995; Schwindt and Crill, 1995; Stuart and Sakmann, 1995). Under these conditions, the distal dendrites could generate responses that are independent of more proximal cellular regions (Cauller and Connors, 1994). Inhibitory inputs originating from layer I neurons could selectively target distal dendrites and therefore may play an important role in local integration. Both apical dendrites and axon collaterals from pyramidal neurons reach layer I. Thus, it is possible that layer I neurons serve in a feedback inhibitory circuit. The dense but confined axonal projection of neurogliaform cells is particularly intriguing in that regard, suggesting that these cells function as local inhibitory neurons within specific local domains in layer I. In contrast, cells with descending axons are positioned to make contacts throughout the thickness of cortex. Whether the targets include the proximal portions of apical pyramidal cell dendrites as well as nonpyramidal cell elements remains to be determined.

\section{REFERENCES}

Amitai Y, Friedman A, Connors BW, Gutnick MJ (1993) Regenerative activity in apical dendrites of pyramidal cells in neocortex. Cereb Cortex 3:26-38.

Anderson JC, Martin KAC, Picanço-Diniz CW (1992) The neurons in layer 1 of cat visual cortex. Proc R Soc Lond [Biol] 248:27-33.

Bayer SA, Altman J (1990) Development of layer I and the subplate in the rat neocortex. Exp Neurol 107:48-62.

Beaulieu C, Colonnier M (1985) A laminar analysis of the number of round-asymmetrical and flat-symmetrical synapses on spines, dendritic trunks, and cell bodies in area 17 of the cat. J Comp Neurol 231:180-189.

Beaulieu C, Campistron G, Crevier C (1994) Quantitative aspects of the GABA circuitry in the primary visual cortex of the adult rat. J Comp Neurol 339:559-572.

Caeser M, Brown DA, Gähwiler BH, Knöpfel T (1993) Characterization of a calcium-dependent current generating a slow afterdepolarization of CA3 pyramidal cells in rat hippocampal slice cultures. Eur J Neurosci 5:560-569.

Cauller LJ, Connors BW (1994) Synaptic physiology of horizontal afferents to layer I in slices of rat SI neocortex. J Neurosci 14:751-762.

Condé F, Lund JS, Jacobowitz DM, Baimbridge KG, Lewis DA (1994) Local circuit neurons immunoreactive for calretinin, calbindin D-28k or parvalbumin in monkey prefrontal cortex: distribution and morphology. J Comp Neurol 341:95-116.

Connors BW, Gutnick MJ (1990) Intrinsic firing patterns of diverse neocortical neurons. Trends Neurosci 13:99-104.

Constanti A, Bagetta G, Libri V (1993) Persistent muscarinic excitation in guinea-pig olfactory cortex neurons: involvement of a slow poststimulus afterdepolarizing current. Neuroscience 56:887-904.

DeFelipe J, Jones EG (1988) Cajal on the cerebral cortex: an annotated translation of the complete writings. Oxford: Oxford UP.

del Rio JA, Martínez A, Fonseca M, Auladell C, Soriano E (1995) Glutamate-like immunoreactivity and fate of Cajal-Retzius cells in the murine cortex as identified with calretinin antibody. Cereb Cortex 5:13-21.

Derer P, Derer M (1990) Cajal-Retzius cell ontogenesis and death in mouse brain visualized with horseradish peroxidase and electron microscopy. Neuroscience 36:839-856.

Edwards FA, Konnerth A, Sakmann B, Takahashi T (1989) A thin slice preparation for patch clamp recordings from neurones of the mammalian central nervous system. Pflügers Arch 414:600-612. 
Foehring RC, Waters RS (1991) Contributions of low-threshold calcium current and anomalous rectifier (Ih) to slow depolarizations underlying burst firing in human neocortical neurons in vitro. Neurosci Lett $12: 17-21$

Foehring RC, Lorenzon NM, Herron P, Wilson CJ (1991) Correlation of physiologically and morphologically identified neuronal types in human association cortex in vitro. J Neurophysiol 66:1825-1837.

Friedman A, Gutnick MJ (1987) Low-threshold calcium electrogenesis in neocortical neurons. Neurosci Lett 81:117-122.

Friedman A, Arens J, Heinemann U, Gutnick MJ (1992) Slow depolarizing afterpotentials in neocortical neurons are sodium and calcium dependent. Neurosci Lett 135:13-17.

Gabbott PL, Somogyi P (1986) Quantitative distribution of GABAimmunoreactive neurons in the visual cortex (area 17) of the cat. Exp Brain Res 61:323-331.

Geiger JR, Melcher T, Koh DS, Sakmann B, Seeburg PH, Jonas P, Monyer H (1995) Relative abundance of subunit mRNAs determines gating and $\mathrm{Ca}^{2+}$ permeability of AMPA receptors in principal neurons and interneurons in rat CNS. Neuron 15:193-204.

Hablitz JJ, Zhou FM (1995) Dual component mEPSCs in layer I neurons of rat neocortex. Soc Neurosci Abstr 21:2022.

Hedlich A, Werner L (1987) Neuroglioforme Zellen im visuaellen cortex der ratte. J Hirnforsch 29:107-116.

Hestrin S (1993) Different glutamate receptor channels mediate fast excitatory synaptic currents in inhibitory and excitatory cortical neurons. Neuron 11:1083-1091.

Huguenard JR, Hamill OP, Prince DA (1989) Sodium channels in dendrites of rat cortical pyramidal neurons. Proc Natl Acad Sci USA 86:2473-2477.

Huntley GW, Jones EG (1990) Cajal-Retzius neurons in developing monkey neocortex show immunoreactivity for calcium binding proteins. J Neurocytol 19:200-212.

Jones EG (1984) Neurogliaform or spiderweb cells. In: Cerebral cortex (Peters A, Jones E, eds), pp 409-418. New York: Plenum.

Jonas P, Racca C, Sakmann B, Seeburg PH, Monyer H (1994) Differences in $\mathrm{Ca}^{2+}$ permeability of AMPA-type glutamate receptor channels in neocortical neurons caused by differential GluR-B subunit expression. Neuron 12:1281-1289.

Kawaguchi Y (1993) Grouping of nonpyramidal and pyramidal cells with specific physiological and morphological characteristics in rat frontal cortex. J Neurophysiol 69:416-431.

Kawaguchi Y (1995) Physiological subgroups of nonpyramidal cells with specific morphological characteristics in layer II/III of rat frontal cortex. J Neurosci 15:2638-2655.

Kawaguchi Y (1996) Physiological and morphological identification of somatostatin- or vasoactive intestinal polypeptide-containing cells among GABAergic cell subtypes in rat frontal cortex. J Neurosci 16:2701-2715.

Kawaguchi Y, Kubota Y (1993) Correlation of physiological subgroupings of nonpyramidal cells with parvalbumin- and calbindinD28kimmunoreactive neurons in layer $\mathrm{V}$ of rat frontal cortex. J Neurophysiol 70:387-396.

Kim HG, Connors BW (1993) Apical dendrites of the neocortex: correlation between sodium- and calcium-dependent spiking and pyramidal cell morphology. J Neurosci 13:5301-5311.

Kim HG, Fox K, Connors BW (1995) Properties of excitatory synaptic events in neurons of primary somatosensory cortex of neonatal rats. Cereb Cortex 5:148-157.

Kriegstein AR, Suppes T, Prince DA (1987) Cellular and synaptic physiology and epileptogenesis of developing rat neocortical neurons in vitro. Dev Brain Res 34:161-171.
Lambolez B, Ropert N, Perrais D, Rossier J, Hestrin S (1996) Correlation between kinetics and RNA splicing of alpha-amino-3-hydroxy-5methylisoxazole-4-propionic acid receptors in neocortical neurons. Proc Natl Acad Sci USA 93:1797-1802.

Li J, Schwark HD (1994) Distribution and proportions of GABAimmunoreactive neurons in cat primary somatosensory cortex. J Comp Neurol 343:353-361.

Lorenzon NM, Foehring RC (1993) The ontogeny of repetitive firing and its modulation by norepinephrine in rat neocortical neurons. Dev Brain Res 73:213-223.

Magee JC, Christofi G, Miyakawa H, Christie B, Lasser-Ross N, Johnston D (1995) Subthreshold synaptic activation of voltage-gated $\mathrm{Ca}^{2+}$ channels mediates a localized $\mathrm{Ca}^{2+}$ influx into the dendrites of hippocampal pyramidal neurons. J Neurophysiol 74:1335-1342.

Marin-Padilla M (1984) Neurons of layer I: a developmental analysis. In: Cerebral cortex (Peters A, Jones EG, eds), pp 447-475. New York: Plenum.

Martin KAC, Friedlander MJ, Alones V (1989) Physiological, morphological, and cytochemical characteristics of a layer 1 neuron in cat striate cortex. J Comp Neurol 282:404-414.

Martínez-García F, Gonzalez-Hernandez T, Martínez-Millan L (1994) Pyramidal and nonpyramidal callosal cells in the striate cortex of the adult rat. J Comp Neurol 350:439-451.

McCormick DA, Prince DA (1987) Post-natal development of electrophysiological properties of rat cerebral pyramidal neurones. J Physiol (Lond) 392:743-762

McCormick DA, Connors BW, Lighthall JW, Prince DA (1985) Comparative electrophysiology of pyramidal and sparsely spiny stellate neurons of the neocortex. J Neurophysiol 54:782-806.

Ogawa M, Miyata T, Nakajima K, Yagyu K, Seike M, Ikenaka K, Yamamoto H, Mikoshiba K (1995) The reeler gene-associated antigen on Cajal-Retzius neurons is a crucial molecule for laminar organization of cortical neurons. Neuron 14:899-912.

Pockberger H (1991) Electrophysiological and morphological properties of rat motor cortex neurons in vivo. Brain Res 539:181-190.

Prieto JJ, Peterson BA, Winer JA (1994) Morphology and spatial distribution of GABAergic neurons in cat primary auditory cortex (AI). J Comp Neurol 344:349-382.

Ramon y Cajal S (1911) Histologie du System Nerveux de l'Homme et des Vertebrates. (Translated into English by N Swanson and LW Swanson as Histology of the Nervous System of Man and Vertebrates.) Oxford: Oxford UP, 1995.

Sah P (1996) $\mathrm{Ca}^{2+}$-activated $\mathrm{K}^{+}$currents in neurones: types, physiological roles and modulation. Trends Neurosci 19:150-154.

Schwindt PC, Crill WE (1995) Amplification of synaptic current by persistent sodium conductance in apical dendrite of neocortical neurons. J Neurophysiol 74:2220-2224.

Schwindt PC, Spain WJ, Foehring RC, Chubb MC, Crill WE (1988) Slow conductances in neurons from cat sensorimotor cortex in vitro and their role in slow excitability changes. J Neurophysiol 59:450-467.

Sousa-Pinto A, Paula-Barbosa M, Carmo-Matos M (1975) A Golgi and electron microscopical study of nerve cells in layer I of the cat auditory cortex. Brain Res 95:443-458.

Stuart G, Sakmann B (1995) Amplification of EPSPs by axosomatic sodium channels in neocortical pyramidal neurons. Neuron 15:1065-1076.

Winer JA, Larue DT (1989) Populations of GABAergic neurons and axons in layer I of rat auditory cortex. Neuroscience 33:499-515.

Zhou F-M, Hablitz JJ (1996) Postnatal development of membrane properties of layer I neurons in rat neocortex. J Neurosci 16:1131-1139. 